\title{
Effectiveness of the European Semester: Explaining Domestic Consent and Contestation
}

\author{
Aleksandra Maatsch* \\ Department of Social Sciences, University of Cologne, Cologne, Germany \\ *Correspondence: maatsch@wiso.uni-kolen.de
}

Which factors explain domestic consent or contestation of European Union (EU) policy guidance issued within the framework of the European Semester (ES)? To address this question, this article analyses national parliamentary party positions on EU policy guidance in two cycles of the ES (2014 and 2015) in Austria, France, Germany and Ireland. Whereas parliamentary parties in Austria and Ireland expressed their consent to EU policy guidance, parliamentary parties in Germany and France were polarised. The empirical analysis presented in this article establishes that strong formal powers in budgetary matters are a prerequisite for parties to contest EU policy guidance. However, parliamentary party positions depend most on whether the content of EU policy guidance reflects a party's economic interests.

Keywords: European economic governance, European Semester, National parliaments, Political parties

\section{Introduction}

The European Semester has received significant academic attention since its introduction. The literature so far has focused on questions related to accountability within the mechanism (Scharpf, 2012; Curtin, 2014; Crum and Curtin, 2015; Dawson, 2015; Crum, 2017 also: Cygan et al. in this volume) as well as the adaptation of national parliaments (NPs) to the European Semester (Hallenberg et al., 2011; Fasone, 2013; Jančić, 2016; Kreilinger, 2016;Crum, 2017). However, one aspect of the European Semester, namely its effectiveness, has received significantly less academic attention (Kreilinger, 2016). The effectiveness of the European Semester, defined as successful implementation of EU policy guidance, has been extremely low: depending on the method of evaluation, EU Member States 
implement less than 20\% of EU policy guidance (Bekker, 2016; Kreilinger, 2016). Given that EU decision-makers recognise the low effectiveness of the European Semester as particularly worrying, it is necessary to examine in detail, which factors account for the current situation. This article aims to address this need by posing the following question: which factors account for the willingness (or lack of willingness) of national parliamentary parties to follow EU policy guidance issued within the framework of the European Semester? ${ }^{1}$

The European Semester, in force since 2011, is an institutional instrument for the surveillance of EU Member States' economic and fiscal policies, and its goal is to ensure closer coordination of economic policies and convergence of the economic performance of the Member States. The mechanism has brought about two important innovations. First, national budgetary processes have become coordinated so that the European Commission has sufficient time to provide recommendations to the Member States before NPs approve their budgets. Secondly, EU-level control has been extended beyond public finances and now covers changes in the Member States' competitiveness (or relative prices).

The European Semester constitutes a soft governance tool: the Commission monitors compliance with 'hard' (budgetary) and 'soft' (socio-economic) criteria, but it cannot veto national budgets which are (still) tailored by national governments (Ruiz Almendral, 2015). Although the new institutional framework envisages sanctions, no government that has breached the criteria has so far been punished. As the literature observes, this practice confirms that the European Semester is a de facto non-constraining mechanism (Crum, 2017).

Given this non-constraining character, the effectiveness of the mechanism eventually depends on whether domestic actors choose to implement EU policy guidance. The literature notes that the weaker the knowledge and 'ownership' by domestic actors of the mechanisms of EU policy guidance, and the weaker the formal powers of NPs in budgetary issues, the less willing domestic actors are to follow EU policy guidance (Kreilinger, 2016). The assumption behind the argument is that domestic actors are, in principle, committed to EU policy guidance but they either lack the knowledge of the European Semester, or their formal powers in budgetary matters are not strong enough to participate actively within the European Semester. In other words, the effectiveness of the European Semester would be better, if NPs had more information concerning the mechanism and more possibilities to engage with it.

The literature seems, however, to have overlooked the vital importance of national economic conflict lines. The European Semester has become an integral

\footnotetext{
${ }^{1}$ The first preliminary results of this comparative study were published as a book-chapter in the volume edited by Jančić, D. (2017) National Parliaments after the Lisbon Treaty and the Euro Crisis, Oxford, Oxford University Press.
} 
part of the domestic budgetary process, which is structured by the domestic conflict over redistributive policies. These policies are of central importance in domestic politics. It seems, therefore, likely that a willingness to follow EU policy guidance would be influenced by the economic preferences of parties and of their constituents. However, the role of domestic economic conflict lines has not yet been analysed in the context of the European Semester. This article aims to fill this gap.

This article contributes to the debate by analysing which factors account for national parliamentary party consent or contestation of EU policy guidance issued within the framework of the European Semester. Using Austria, Germany, France and Ireland as case studies, the article investigates NPs' activities during two cycles (2014 and 2015) of the European Semester. The article analyses parliamentary party positions (not only government positions) to reconstruct national conflict lines. The article does not focus on de facto implementation because most policy guidance concerns measures that have to be implemented over a longer period of time. As a result, it is difficult to observe and measure the effects of EU policy guidance shortly after its issuance. However, an analysis of parliamentary party positions on EU policy guidance issued within each budgetary cycle allows us to establish which measures are likely to be implemented in the future and why.

The article begins by reviewing the literature on the factors that shape parliamentary party positions on EU policy guidance. It then presents the study's research design and methodological approach followed by a discussion of the empirical findings. The findings suggest that conflict over EU policy guidance has been structured along domestic economic interests. Parliamentary parties contest EU policy guidance when it stands in conflict to their economic interests. As the literature suggests, strong formal powers of NPs in budgetary policy also matter. However, contrary to the expectation raised in the literature, strong formal powers facilitate contestation (not consent) of EU policy guidance.

\section{What factors account for consent or contestation of EU policy guidance?}

According to the literature, parliamentary activity to a significant extent depends on the strength of NPs' formal competences in a given policy area (Rittberger and Winzen, 2015; Maatsch, 2017). Formal powers, particularly those stipulated at the constitutional level, delineate the scope of policy activities available to NPs and specify how much influence NPs can exercise over budgetary matters and which forms of oversight they must or may exercise.

Budgetary matters have always been one of the core responsibilities of NPs. Over time, however, NPs have lost their exclusive powers, and today it is the 
executive branch, which usually leads the budgetary process (Ruiz Almendral, 2015). When a parliament enjoys very weak formal powers in budgetary matters, the government encounters fewer difficulties in pursuing its agenda. Consequently, weak parliaments cannot effectively challenge the government or politicise a given issue. The stronger the parliament, particularly the opposition, the more constrained the government is in its activities. The first hypothesis tested in this article thus stipulates that the stronger the formal powers of a NP in budgetary matters, the more likely it is that EU policy guidance is contested.

According to the second hypothesis of this study, governing parties are more likely than opposition parties to voice their consent to EU policy guidance. The literature on NPs and parliamentary parties has demonstrated that the major political cleavage is not between government and parliament, but between government and opposition (Raunio, 2009). The role of the opposition is to challenge the government and propose alternative policy solutions. If a certain policy pursued by the government is socially contested, opposition parties are likely to respond by proposing alternatives (Ezrow et al., 2011). In contrast to governing parties, the opposition does not have to bear the immediate cost of their promises.

Governing parties sometimes have to make unpopular decisions. According to Birch (1964) and Mair (2011), governing party responsibilities imply prudence, consistency and predictability in their actions over a longer period of time, as well as a sense of duty in respecting international norms and commitments that have been made by previous governments. The literature notes that in a situation of conflict between the terms of an international agreement and voters' preferences, governing parties are more likely than opposition parties to adhere to 'international responsibility' (Rose, 2014; Maatsch, 2016). There is thus an expectation that democratic governments, as representatives of their states in the international arena, will respect existing international agreements even if they are not entirely in favour of them.

In the context of the European Semester, it can be expected that governing parties are more concerned with negative externalities of their national policies than opposition parties are. A negative externality occurs when an action by a given actor imposes costs on third parties. The actor generating negative externalities may or may not be negatively affected. In particular, persistent budgetary instability in one Member State may undermine the international credibility of the euro. Governing parties, maintaining direct contacts with other governments of EU Member States and representing their states at the international arena, are less likely than opposition parties to be indifferent with respect to negative externalities of their national policies.

However, political parties usually adhere to the preferences of their voters (constituents), particularly in matters related to redistribution. According to 
classical theories, political parties attempt to accommodate the preferences of the median voter or those of specific constituents (Downs, 1957; Dalton, 1985). Therefore, a third factor that influences the willingness of parliamentary parties to adhere to EU policy guidance is their economic interest. Hence, if the EU institutions recommend budgetary consolidation, right-wing parties are more likely than their left-wing counterparts to support these measures. In contrast, if measures proposed by the Commission better correspond to the economic preferences of left-wing parties, those parties are more likely than their right-wing counterparts to advocate compliance.

In the context of the European Semester, adherence to voters' preferences is likely to be more important for parliamentary parties than avoidance of negative externalities. Parliamentary parties are accountable to domestic constituencies, which are interested primarily in securing their own interests, not the interests of other states or supranational institutions. Parties, as vote- and office-seeking institutions, depend on support from national voters. National parliamentary parties, therefore, find it particularly difficult to eliminate negative externalities when a policy generating these externalities benefits their voters. By the same token, it is easier for parliamentary parties to counter negative externalities when those externalities also affect their states. In other words, national parties are likely to eliminate negative externalities as long as doing so is not associated with high costs.

Consequently, the third hypothesis focuses on the ideological orientation of a party and posits that the more coherent EU policy guidance is with economic preferences of a political party and their constituents, the more likely the party is to adhere to EU guidance. Similarly, if EU guidance cannot be reconciled with the party's stance, parties may be more reluctant to advocate compliance out of fear of losing the support of their constituents.

\section{Research design}

The major role of NPs in the European Semester is to contribute to the legitimacy of the mechanism. NPs, but also the European Parliament, provide oversight of the policy- and decision-making process in that area. In particular, NPs contribute to domestic debates concerning the major documents of the European Semester such as the Annual Growth Survey, Country-Specific Recommendations, National Reform Programmes and National Stability/Convergence Programmes. According to the 21st COSAC report, ${ }^{2}$ the contribution of NPs to the European Semester

\footnotetext{
${ }^{2}$ Twenty-first Bi-annual Report: Developments in European Union Procedures and Practices Relevant to Parliamentary Scrutiny by COSAC, June 2014. http://www.cosac.eu/documents/bi-annual-reportsof-cosacl
} 
varies. Namely, NPs with strong formal powers tend to exercise a more intensive oversight than NPs with weak formal powers.

The scope of the analysis concerns two full budgetary cycles-those in 2014 and 2015. ${ }^{3}$ The dependent variable in this analysis is a position a parliamentary party takes on EU policy guidance. The dependent variable is operationalised as consent or contestation. The EU policy guidance is presented in the yearly country-specific recommendations (prepared for all Member States) as well as in other documents such as the In-Depth Review (prepared for states that require closer monitoring due to macroeconomic imbalances). This study analysed all documents containing EU policy guidance for the states under examination.

The data on the dependent variable was established based on information provided electronically by NPs in each of the selected Member States. The analysis investigated all national parliamentary party activities related to the European Semester during 2014 and 2015. The analysis mapped all activities at the plenary and committee levels in each analysed Member State (see the Appendix for details $\left.^{4}\right)$. Most national parliamentary parties acquire opportunities to position themselves on EU policy guidance during the drafting of National Reform Programmes (concerning social policies) and Stability or Convergence Programmes (budgetary matters). In some states, parliamentary committees also debate the Annual Growth Survey and country-specific recommendations.

The data regarding the formal powers of NPs in budgetary affairs (the first explanatory variable) was established based on legal acts in force in the Member States under study. The classification of parliamentary parties along the government-opposition dimension (the second explanatory variable) drew on the web pages of NPs, while the data on the left-right affiliation of parliamentary parties (the third variable) was based on the PIREDEU classification. ${ }^{5}$ The method employed for the analysis of official documents was qualitative comparative content analysis.

To assess the degree of NPs' powers in budgetary matters, the analysis concentrated on two indicators: (i) the degree of constitutional protection of national parliamentary powers in budgetary matters; and (ii) the degree of formal

\footnotetext{
${ }^{3} \mathrm{~A}$ complete list of all the documents analysed for each state is provided in the Appendix, https://www. researchgate.net/profile/Aleksandra_Maatsch.

${ }^{4}$ The empirical database has been completed with the support of two research assistants, Sarah Herbertz and Dennis Höfer.

${ }^{5}$ Collaborative Project on 'Providing an Infrastructure for Research on Electoral Democracy in the European Union’ http://www.piredeu.eu 17 August 2016.
} 
budgetary constraints on NPs and governments. ${ }^{6}$ The analysis of constitutional provisions clearly demonstrated that the NPs of Germany (Callies and Beichelt 2016) and Austria enjoy stronger formal budgetary powers than those of France and Ireland. Both chambers of the German parliament, the Bundestag and the Bundesrat, are involved in approving the national budget. The budget has to be approved by a vote in each chamber to enter into force (Article 110 of the Basic Law). Furthermore, members of the Bundestag are entitled to present motions aimed, for instance, at decreasing revenues. If an extraordinary situation requires expenditures exceeding the constitutional limit of public debt, the parliament has to approve the bill by a vote. During the recent European financial crisis NPs in Germany and Austria were successful is securing-or even fostering-their powers in EU economic matters (Maatsch, 2017). In contrast, Southern European parliaments and the French parliament were disempowered by the extensive application of fast-track procedures that limited their involvement in the legislative process.

The French Parliament does not enjoy strong constitutional protection. Only the government enjoys the right to initiate a budget. If both chambers fail to approve the Finance Bill within the time limit provided by the Constitution (70 days), the government may bring the provisions into effect. The Irish parliament, the Oireachtas, plays a limited role in the budgetary process. The Dáil, or lower house, cannot pass any vote or resolution in that area unless the government recommends it. Furthermore, according to Article 42 of the constitution, only the government can propose finance bills.

Interestingly, while NPs in Austria and Germany enjoy strong constitutional protection of their budgetary powers, their constitutions also impose significant budgetary constraints on them. In particular, the constitutions of Austria (Article 51 B-VG) and Germany (Article 115 of the Basic Law) each contain a debt-brake provision and a balanced-budget clause. However, both constitutions also stipulate the conditions under which these rules can be violated. In these cases, decisions have to be approved by the NPs. In contrast, the French and Irish constitutions contain no debt brakes or balanced-budget clauses. These matters are regulated by means of secondary legislation.

\footnotetext{
${ }^{6}$ In Germany, Basic Law (Grundgesetz, GG), Articles 110, 113 and 115; Federal Budget Code (Bundeshaushaltsordnung), Section 10. In Austria, Basic Law (Bundesverfassungsgesetz B-VG), Article 51; Rules of Procedure Act (Geschäftsordnungsgesetz des Nationalrates, GO G-NR), Article 14(2); Austrian Federal Council Rules of Procedure (Geschäftsordnung des Bundesrates, GO-BR). In Ireland, the Constitution, Articles 17, 21, 22, and 28. In France, the Constitution (Constitution française), Articles 39, 42, 47 and 49.
} 


\section{Empirical findings}

The study's empirical findings demonstrate that parliamentary party consent or contestation of EU policy guidance depends on a combination of two factors: the strength of NPs' formal powers in budgetary matters and coherence between country-specific recommendations and a party's economic preferences. Contrary to expectations, membership in the government or opposition proved to be irrelevant in explaining parliamentary party positions. In general, political parties represented in the parliaments of Austria and Ireland advocated compliance with their country-specific recommendations, while those in France and Germany were deeply divided on the issue.

\subsection{EU policy guidance in Ireland and Austria: explaining domestic consent}

In Austria and Ireland, parliamentary parties voiced their consent of EU policy guidance. In both states, parliamentary parties agreed that the policy guidance they obtained conformed to their economic interests. In both states, parliamentary oversight takes place predominantly at committee level. In Ireland, weak formal powers prevent parliamentary parties from more intensive involvement with the European Semester. In Austria, in contrast, parliamentary parties have not been interested in engaging with EU policy guidance beyond the committee level. The level of the institutional engagement with the European Semester has had an impact on the style of oversight, meaning that oversight exercised by parliamentary committees has been more detailed and technical but less politicised than plenary discussions.

During the financial crisis, the Irish economy had to be stabilised through a bailout loan from the European Financial Stability Facility. By 2014, the economy was clearly on track to recovery. As a result, although the government had still not met the deficit goal, the Commission evaluated the economic progress of the country rather positively. According to the Commission, the government should concentrate on gradually correcting the excessive deficit, fostering long-term employment and education, preventing poverty among children, monitoring banks' performance and reducing the costs of legal proceedings. The Commission also advised the government to improve cost-effectiveness in the healthcare system. In 2015, the recommendations again focused on public policies and monitoring the banks' performance.

Because the Oireachtas enjoys very weak constitutional protection in budgetary matters, the low level of activity in the Dáil did not come as a surprise. In the plenary, parliamentary parties were involved in the approval of the Finance Bill. However, the two cornerstones of the European Semester, the National Reform Programme and the Stability Programme, were debated in committee only. Two 
committees led the process: the Joint Committee on European Union Affairs and the Committee on Finance, Public Expenditure and Reform. The two committees engaged systematically with the European Semester. Yet the activity was predominantly of technocratic, not political, nature: the committees mainly focused on procedures of the European Semester. The committees have not devoted a lot of attention to the impact of the EU policy guidance on domestic social policies.

In January 2014, there was a plenary debate on the Commission's Annual Growth Survey. In spring 2014, the Joint Committee on EU Affairs debated the European Semester (in general) as well as the National Reform Programme. The committee members observed that the timing of the Semester was too tight for NPs to contribute substantially to the process. The discussion was predominantly focused on clarifying details concerning particular country-specific recommendations. In June 2014, the committee debated on country-specific recommendations. While there was no disagreement regarding these recommendations, the committee did observe that they were too general: it had expected more specific guidelines concerning, for instance, job creation.

In January 2015, the Committee on Finance, Public Expenditure and Reform debated the Annual Growth Survey, concluding that it should be involved more closely in the European Semester. The National Reform Programme was discussed in the Joint Committee on EU Affairs, which concluded that the European Semester was very important for Europe. Its chairman initiated a discussion on how NPs could be better involved in the process.

The country-specific recommendations were debated in the Committee on Finance, Public Expenditure and Reform. The guest speaker, Commissioner Moscovici, noted that the Commission acknowledged the progress that Ireland had made and observed that Ireland's economic recovery had been impressive, but that there were 'still legacies of the crisis that continue to create risks for the country'. The committee members specifically enquired whether the Commission expected Ireland to implement each and every recommendation. The commissioner answered in the affirmative, but also noted that some recommendations were expected to take a few years to implement. The discussion on country-specific recommendations continued in the Joint Committee on EU Affairs, where it revolved around their interpretation and implementation. In September, the committee discussed the Five Presidents' Report. The guest speaker was José Leandro, the Principal Advisor on Economic Monetary Union (EMU) to the President of the European Commission, Jean-Claude Juncker, who was asked about the content of the proposed reforms. In October, the committees and both chambers of parliament started working on the Finance Bill, which was approved in December.

${ }^{7}$ Committee on Finance, Public Expenditure and Reform, debate on 26 May 2015. 
In the policy guidance prepared for Austria, the Commission observed that the state should avoid potential deviations from their mid-term objectives. The Commission also recommended reforms of the pension and healthcare systems to ensure their long-term sustainability. According to the Commission, the Austrian government should introduce incentives to limit early retirement. The Commission also recommended improving labour-market participation and reducing the tax burden on labour.

The Austrian Parliament remained thoroughly informed about the progress of the budgetary process. Nonetheless, the vast majority of activity related to the European Semester was carried out at the committee level. In particular, the government communicated intensively with the committees evaluating the Stability Programme and the National Reform Programme. The committees issued communiqués in which they summarised the content of the documents. The 2014 and 2015 country-specific recommendations for Austria did not antagonise the parliamentary parties. All parties represented in the committees agreed on the longterm need to reform the pension system due to Austria's ageing population. There was also general agreement that participation in the labour market could be improved. Plenary activity focused on the national budget; however, neither the National Reform Programme nor the Stability Programme was debated in detail.

\subsection{Explaining domestic contestation of EU policy guidance in Germany and} France

In Germany and France, EU policy guidance has generated deep conflict among parliamentary parties. In both states, the conflict has had ideological underpinnings: parliamentary parties have contested EU policy guidance when it has conflicted with their constituents' interests and the party's general economic stance. The government-opposition cleavage has proven to be irrelevant in explaining consent or contestation of EU policy guidance. In particular, governing parties have not been more likely than opposition parties in welcoming EU policy guidance.

In Germany, the European Semester became rather controversial. In particular, the $\mathrm{CDU} / \mathrm{CSU}^{8}$ and the $\mathrm{SPD}^{9}$ contested EU policy guidance, while the Greens ${ }^{10}$ and the Left ${ }^{11}$ welcomed it. In 2014 and 2015, Germany became subject

${ }^{8}$ Christlich Demokratische Union Deutschlands (Christian Democratic Union of Germany), CDU; and Christlich-Soziale Union in Bayern (Christian Social Union in Bavaria), CSU.

${ }^{9}$ Sozialdemokratische Partei Deutschlands (Social Democratic Party of Germany), SPD.

${ }^{10}$ Bündnis 90/Die Grünen (Alliance 90/the Greens).

${ }^{11}$ Die Linke (the Left). 
to an In-Depth Review due to its overall current account imbalance. The Commission observed that the German surplus (ca. 8\%) required 'decisive policy action and monitoring. ${ }^{12}$ As a result, in 2014, the Commission recommended that Germany 'improve conditions for further support of domestic demand'. According to the Commission, the imbalance could be effectively reduced if the German government undertook steps to foster domestic demand. The German government was particularly encouraged to increase public investment and reduce taxes on security contributions for low-wage earners. The Commission advocated reducing fiscal disincentives to work as well as facilitating a transition from the 'mini-job' sector to regular forms of employment. Finally, the Commission recommended further reforms aimed at securing the sustainability of public pensions and later retirement. The government was also urged to address childcare shortages.

In 2015, the country-specific recommendations revolved around the same themes. In the In-Depth Review, the Commission complained that

Germany has made limited progress in addressing the 2014 countryspecific recommendations. As regards policies relevant to the Macroeconomic Imbalance Procedure, some steps were taken to increase public investment, but they appear insufficient to address the investment backlog in infrastructure, education and research. No measures were taken to improve the efficiency of the tax system or reduce high taxes and social contributions. The potential of the general minimum wage to foster private consumption may be limited .... Fiscal disincentives to work have not been tackled. No significant efforts have been made to stimulate competition in the railway and service sectors. ${ }^{13}$

These country-specific recommendations have polarised parliamentary parties in Germany across different economic interests. The centre-left SPD and the centreright CDU/CSU have positioned themselves against country-specific recommendations, while the leftist Greens and the Left (radical left) have welcomed the recommendations as serving interests of low-wage earners. Contrary to expectations, the governing parties, the CDU/CSU and the SPD, have not prioritised international responsibility but rather economic interests of German export industries.

\footnotetext{
${ }^{12}$ European Commission, 'European Economy - Macroeconomic Imbalances Germany 2014', Occasional Papers 174, March 2014 http://ec.europa.eu/economy_finance/publications/occasional_ paper/2014/pdf/ocp174_en.pdf 17 August 2016.

${ }^{13}$ European Commission, 'European Economy: Macroeconomic Imbalances Country Report Germany 2015’, Occasional Papers 214, June 2015 http://ec.europa.eu/economy_finance/publications/ occasional_paper/2015/pdf/ocp214_en.pdf 17 August 2016.
} 
In April 2014, the Green Party initiated a plenary debate on a draft resolution that it tabled under the title 'National Reform Programme 2014: Taking the Economic Coordination in the EU Seriously and Fostering Investment'. ${ }^{14}$ In it, the party voiced concern about the persisting trade surplus in Germany and urged the government to implement the country-specific recommendations. It proposed tackling the problem by strengthening domestic consumption. According to the party, stronger domestic consumption-generated, for instance, by wage increases - would boost imports and thus reduce the trade imbalance. The Green Party's resolution was reviewed by the Committee for Economic Affairs and Energy. Following a formal recommendation by this Committee, the Bundestag rejected the resolution in a vote.

During the plenary debate, the Green Party also criticised the SPD and the CDU/CSU for not being truly committed to EU economic governance. The Greens noted that the government had done little to promote parliamentary discussion on the National Reform Programme. In their view, if it were not for the initiative of the Green Party, the Bundestag would have missed an opportunity to discuss the Programme.

In 2015, the Left Party proposed a resolution entitled 'Diminishing Trade Surpluses and Changing the Wage Policy', ${ }^{15}$ which was also debated and put to a vote in a plenary session. The Left predominantly concentrated on the domestic economic consequences of the trade imbalance. The party observed very critically that wages had been suppressed for more than 15 years. Furthermore, in many sectors of the German economy precarious work contracts had become dominant. The party urged the government to diminish the trade surplus by fostering domestic consumption. According to the party, the minimum wage should be increased and precarious work contracts restricted. Finally, the Left observed that the coalition sought to turn the European Semester into a mechanism to punish governments for budgetary deficits but not for macroeconomic imbalances. Eventually, the Left's resolution was also rejected.

The governing coalition maintained that the trade imbalance was small and hence not actually dangerous. In their view, the imbalance was a result of increased exports to third countries and not to EU Member States. The coalition also noted that the German trade surplus contributed to the creation of new jobs abroad and thus should not be perceived so negatively. In the view of the coalition, the policies proposed by the Green Party should be handled with care.

\footnotetext{
${ }^{14}$ Bundestag, Drucksache 18/978 of 2 February 2014, 'Antrag: Nationalesreformprogramm 2014 nützen, wirtschaftspolitische Steuerung in der EU ernst nehmen und Investitionen stärken' http://dip21. bundestag.de/dip21/btd/18/009/1800978.pdf 17 August 2016.

${ }^{15}$ Bundestag, Drucksache 18/4837 of 6 May 2015, 'Antrag: Exportüberschüsse abbauen - Wende in der Lohnpolitik einleiten' http://dip21.bundestag.de/dip21/btd/18/048/1804837.pdf 17 August 2016.
} 
According to the coalition, permanent contracts would limit the flexibility of the labour market. Furthermore, wage increases could have a negative impact on German exports and thereby reduce employment in domestic export industries. Nonetheless, the coalition stressed its commitment to implementing countryspecific recommendations by increasing expenditures on research, education and infrastructure.

During the plenary debate on the Left Party's resolution, the coalition clearly stated that deficits were more economically hazardous than macroeconomic imbalances. When the Left observed that trade imbalances had also contributed to the recent economic crisis in Europe, the coalition responded that 'in some EU states the crisis has been an effect of domestic factors'. ${ }^{16}$ Furthermore, the coalition referred to a yearly expert report on the general economic condition of the state, ${ }^{17}$ which urged the government not to introduce any measures aimed at decreasing the trade surplus. During the question hour held on 14 January 2015 on 'the German Budget 2014 without New Debt', the coalition argued that 'It would have been easy for Angela Merkel to give in to international pressure and say, "Alright, let's spend some 20 billion on investment and, by the same token, increase the debt". She didn't do that. She supports the policy of growth-oriented consolidation' 18

In a letter to Commissioner Jyrki Katainen, the German Minister of Finance, Wolfgang Schäuble and the German Minister of Economic Affairs and Energy, Sigmar Gabriel, proposed reforming the European Semester. ${ }^{19}$ The coalition defended the export-oriented growth model and attempted to downplay the negative effect of the German trade surplus. The major points raised in the letter were repeated later in a resolution drafted by the CDU/CSU and the SPD entitled 'Strengthening, Better Implementation of and Further Development of the European Semester'. ${ }^{20}$ In the letter, the ministers advocated closer cooperation

\footnotetext{
${ }^{16} 21.05 .2015$, Bundestag. http://dipbt.bundestag.de/doc/btp/18/18106.pdf

${ }^{17}$ ibid.

${ }^{18 c}$ Es wäre leicht für die Bundeskanzlerin gewesen, dem internationalen Druck nachzugeben und zu sagen: "Ach komm, lasst uns 20 Milliarden für Investitionen oder Ähnliches in die Hand nehmen”, und damit die Verschuldung in die Höhe zu treiben. Sie hat es aber nicht getan. Sie unterstützt die Linie der wachstumsorientierten Konsolidierung'. Barthle, R. (CDU/CSU), Bundestag, 14 January 2015.

${ }^{19}$ Letter no. 2014/0750485 of 20 October $2014<$ http://www.bmwi.de/BMWi/Redaktion/PDF/B/briefgabriel-schaeble-an-eu-kommission, property $=$ pdf,bereich $=$ bmwi2012, sprache $=$ de, $r w b=$ true.pdf $>$ accessed 17 August 2016.

${ }^{20}$ Bundestag, Drucksache 18/4426 of 24 March 2015, 'Das ES stärken, besser umsetzen und weiterentwickeln’ <http://dip21.bundestag.de/dip21/btd/18/044/1804426.pdf> accessed 17 August 2016.
} 
between NPs, national social partners and EU actors within the European Semester. In their opinion, the Commission should prepare country-specific recommendations in cooperation with national ministries, not the permanent representation in Brussels. The coalition's resolution was approved by parliament.

In 2014, the French Prime Minister Manuel Valls announced that the key documents related to the European Semester should be debated in parliament to foster dialogue and cooperation among all parliamentary parties. As a result, in 2014 the French parliament debated the Stability and Reform Programme, the National Reform Programme, the financial policy framework and France's country-specific recommendations.

In March 2014, France became subject to the 'corrective arm' of the Stability and Growth Pact, which means that the Commission began an In-Depth Review of the state's economic performance. The key objective of the French government was to bring the deficit below 3\%. Although the Commission welcomed the government's programme of saving 50 billion Euros from the budget, it concluded that such a fiscal effort remained below the recommended level.

The same year, the Commission recommended meeting the 3\% target by limiting social security spending, reducing administrative personnel, cutting labour costs, decreasing corporate taxes, promoting competitiveness in services and modernising vocational training. In 2015, the French government managed to negotiate an extension until 2017 to correct the deficit. The Commission observed that the slow pace of growth and low inflation in the EU made it particularly difficult for the French government to bring the deficit under the 3\% threshold. In 2015, the Commission recommended correcting the excessive deficit by identifying savings opportunities across all sub-sectors. Finally, the Commission encouraged investment and incentives for the unemployed to return to work, as well as a broader availability of open-ended contracts.

Responding to the Commission's pressure, French President François Hollande adopted an economic approach combining harsh consolidation with growth-oriented policies (Clift, 2014). However, the left wing of the governing Socialist Party severely contested his approach as well as the EU policy guidance. In 2014, divisions within the Socialist Party became so deep that 41 party members abstained when Parliament voted on the Stability and Growth Programme.

As in Germany, the dominant conflict line in the French parliament concerned economic preferences. The centre-right parties, the $\mathrm{UMP}^{21}$ and the UDI, ${ }^{22}$ welcomed EU policy guidance, while the leftist and communist political group, the

\footnotetext{
${ }^{21}$ Union Pour un Mouvement Populaire (Union for a Popular Movement).

${ }^{22}$ L'Union des Démocrates et Independents (Union of Democrats and Independents).
} 
GDR, ${ }^{23}$ opposed it. The ruling socialist party was internally divided on the subject.

The Finance Minister, Michel Sapin, announced that the government's primary goals were to restore the French economy and the country's international credibility in economic matters. ${ }^{24}$ Parliamentary parties responded differently to the government's agenda. While the UMP and UDI remained sceptical of the feasibility of the government's plan, the EELV ${ }^{25}$ and GDR criticised its essence. In particular, the UDI argued that France would be unlikely to bring the deficit level below 3\% in the short term. The GDR was highly critical of the government's approach combining budgetary consolidation with growth-oriented policies. According to the GDR, the approach would probably contribute to prolonged stagflation.

The polarisation of the political scene also manifested itself during the adoption of the budget that took place in autumn 2014. The internal split within the Socialist Party surfaced again. Its left wing accused the Commission of interfering in France's sovereignty, specifically referring to the recommendation to reform the constitutional provisions on the minimum wage. The UDI supported the annual budget but found the internal split within the Socialist Party unacceptable and irresponsible. The GDR criticised the governing party for abandoning its electoral commitment to growth-oriented policies.

In April 2015, the Prime Minister announced that neither the Stability and Growth Programme nor the National Reform Programme should be voted on in the plenary that year. Still, Parliament became involved in the adoption of the budget for 2016, which, to a limited extent, addressed the Stability Programme. At the committee level, there were a few discussions concerning the European Semester, which, however, remained technical and procedural. In the plenary and the committees, many parliamentarians expressed their criticism of the Prime Minister's decision to exclude Parliament from the European Semester.

In March 2015, there was a brief discussion in the Committee for Finance, the Economy and Budgetary Control of the Assemblée Nationale, the lower house, which was devoted to the extension of the deadline for the correction the deficit by 2017 . However, the discussion was merely aimed at information sharing. The following month, this committee also reviewed the draft Stability Programme. In June, the committee teamed up with the European Affairs Committee to host Pierre Moscovici, the incumbent European Commissioner for Economic and

\footnotetext{
${ }^{23}$ Gauche Démocrate et Républicaine (Democratic and Republican Left).

${ }^{24}$ Committee for Finance, the Economy and Budgetary Control, meeting of 21 January 2014.

${ }^{25}$ Europe Ecologie Les Verts (Europe Ecology - the Greens).
} 
Financial Affairs, who elaborated on the reform of the European Semester. The meeting had a technocratic character.

In sum, the non-involvement of Parliament in the European Semester process in 2015 eliminated the political discussion on the EU policy guidance for France. The few meetings that took place at the committee level did not allow for a broad and in-depth discussion among all parliamentary parties.

\section{Discussion}

This article has presented an analysis of national parliamentary party positions (defined as consent or contestation) on EU policy guidance in two cycles of the European Semester - those of 2014 and 2015-in Austria, France, Germany and Ireland. While in Austria and Ireland parliamentary parties expressed their consent to the EU policy guidance, in France and Germany it has been heavily contested. The empirical analysis has established that parliamentary party positions depend on a combination of two factors: the strength of the NP's formal powers in budgetary matters and coherence between the EU policy guidance and the economic preferences of the parties. Strong parliamentary formal powers in budgetary matters constitute an important prerequisite for parliamentary parties to articulate their contestation. Therefore, parliaments with strong formal powers are more institutionally prepared to contest EU policy guidance. However, consent to EU policy guidance depends most on whether it is coherent with political party (and constituent) economic interests. In particular, contestation is more likely if a NP enjoys strong formal powers in budgetary matters and the EU policy guidance conflicts with a given political party's economic interest. The likelihood of parliamentary parties welcoming EU policy guidance is higher when a NP has weak formal powers in budgetary matters and when the recommendations are consistent with parliamentary party economic preferences.

The dominant role of economic interests in explaining political party positions on EU policy guidance demonstrates that the European Semester has become an integral part of the domestic budgetary process, which is structured by the conflict over redistribution. Parliamentary parties have contested EU policy guidance when it has been in conflict with the economic interests of their constituents. By the same token, parties have fulfilled their constitutive representative role. The findings demonstrate that the European Semester has become an opportunity for parliamentary parties to 'domesticate' European economic governance (Kröger and Bellamy, 2016). However, for national political actors, the remaining challenge is to balance constituent demands with the economic interests of the Eurozone and the EU as a whole.

Given the predominance of economic interests in explaining contestation of EU policy guidance, it is unlikely that a longer and a more intensive involvement 
of parliamentary parties with the European Semester would foster domestic consent to EU policy guidance. Parliamentary parties have not contested the guidance because of their unfamiliarity with the European Semester or because of their weak formal powers in budgetary matters.

The empirical findings demonstrate that formal powers in budgetary matters play an important, though different than expected role. Consent to EU policy guidance, rather than being higher, is lower the stronger national parliamentary powers in budgetary matters are.

It is easier for parliamentary parties to politicise EU policy guidance at the plenary than at the committee level. Parliamentary committees conduct policy oversight in a way different to the plenary, whereas committees devote more attention to procedural issues and technical details, plenary debates focus on the broad political and economic implications of a given policy. However, only parliaments with strong formal powers enjoy the privilege of debating EU policy guidance in the plenary.

Finally, for governing parties, domestic economic interests proved to be more important than a responsibility to avoid negative policy externalities. This finding should not be surprising given the fact that national parties are only accountable to national voters. The finding also demonstrates the immense difficulty in designing and conducting effective oversight of European economic governance.

The empirical findings of this article suggest general patterns concerning the willingness by national parliamentary parties to follow EU policy guidance within the framework of the European Semester. These patterns should be tested on a larger number of observations and over a longer period of time. Moreover, there is a need for further studies analysing how NPs cooperate with the European Parliament on matters related to the European Semester.

\section{Acknowledgements}

I would like to thank for comments on an earlier draft from the participants at the PADEMIA workshop held at the Cambridge University in November 2014 as well as Ben Crum, Tobias Kunstein and Alexander Spielau.

\section{References}

Bekker, S. (2016) 'Is there flexibility in the European semester process? Exploring interactions between the EU and member states within post-crisis socio-economic governance' SIEPS, 2016:1.

Birch, A. H. (1964) Representative and Responsible Government: An Essay on the British Constitution, London, George Allen \& Unwin.

Calliess, C. and Beichelt, T. (2016) Die Europäisierung des Parlaments. Die europapolitische Rolle von Bundestag und Bundesrat, Berlin, Bertelsmann Stiftung. 
Clift, B. (2014) 'The Hollande Presidency, the Eurozone Crisis and the Politics of Fiscal Rectitude', SPERI Paper no. 10, Sheffield Political Economy Research Institute, Sheffield.

Curtin, D. (2014) 'Challenging Executive Dominance in European Democracy', Modern Law Review, 77, 1-32.

Crum, B. (2017) 'Depoliticisation versus Accountability: what Role for Parliaments in Post-Crisis EU Economic Governance', Journal of European Public Policy.

Crum, B. and Curtin, D. (2015) 'The Challenge of Making EU Executive Power Accountable'. In Piattoni, S. (ed.) The European Union: Democratic Principles and Institutional Architectures in Times of Crisis, Oxford, Oxford University Press, pp. 63-87.

Dalton, R. J. (1985) 'Political Parties and Political Representation. Party Supporters and Party Elites in Nine Nations', Comparative Political Studies, 18: 267-299.

Downs, A. (1957) An Economic Theory of Democracy, New York, Harper.

Ezrow, L., De Vries, C., Steenbergen, M. and Edwards, E. (2011) 'Mean Voter Representation and Partisan Constituency Representation: Do Parties Respond to the Mean Voter Position or to Their Supporters?', Party Politics, 17: 275-301.

Fasone, C. (2013) 'European Economic Governance and Parliamentary Representation. What Place for the European Parliament?', European Law Journal, 20: 164-185.

Hallerberg, M., Marzinotto, B. and Wolff, G. (2012) An Assessment of the European Semester, Brussels, European Parliament.

Jančić, D. (2016) 'National Parliaments and EU Fiscal Integration', European Law Journal, 22: $225-249$.

Kreilinger, V. (2016) 'National Parliaments, Surveillance Mechanism and Ownership in the Euro Area', Jacques Delors Institut Studies and Reports.

Kröger, S. and Bellamy, R. (2016) 'Beyond a Constraining Dissensus: The Role of National Parliaments in Domesticating and Normalising the Politicisation of European Integration', Comparative European Politics, 14: 131-153.

Maatsch, A. (2016) 'Drivers of Political Parties' Voting Behaviour in European Economic Governance: The Ultimate Decline of the Economic Cleavage?', West European Politics, 39: 648-666.

Maatsch, A. (2017) Parliaments and the Economic Governance of the European Union: Talking Shops or Deliberative Bodies?, London, Routledge.

Mair, P. (2011) 'Bini Smaghi vs. The Parties: Representative Government and Institutional Constraints', EUI Working Papers, RSCAS 2011/22, European University Institute, Florence.

Raunio, T. (2009) 'National Parliaments and European Integration: What We Know and Agenda for Future Research', The Journal of Legislative Studies, 15: 317-334. 
Rittberger, B, Winzen, T. (2015) 'Parlamentarismus nach der Krise: Die Vertiefung Parlamentarischer Asymmetrie in der Reformierten Wirtschafts- und Währungsunion', Politische Vierteljahresschrift, 56: 430-456.

Rose, R. (2014) 'Responsible Party Government in a World of Interdependence', West European Politics, 37: 253-269.

Ruiz Almendral, V. (2015) 'A Myopic Economic Constitution? Controlling the Debt and the Deficit without Fiscal Integration', EUI Law Working Paper no. 2015/12, European University Institute, Florence.

Scharpf, F. W. (2012) 'Legitimacy Intermediation in the Multilevel European Polity and its Collapse in the Euro Crisis', MPifG Discussion Paper no. 12-6, Max Planck Institute for the Study of Societies, Cologne. 